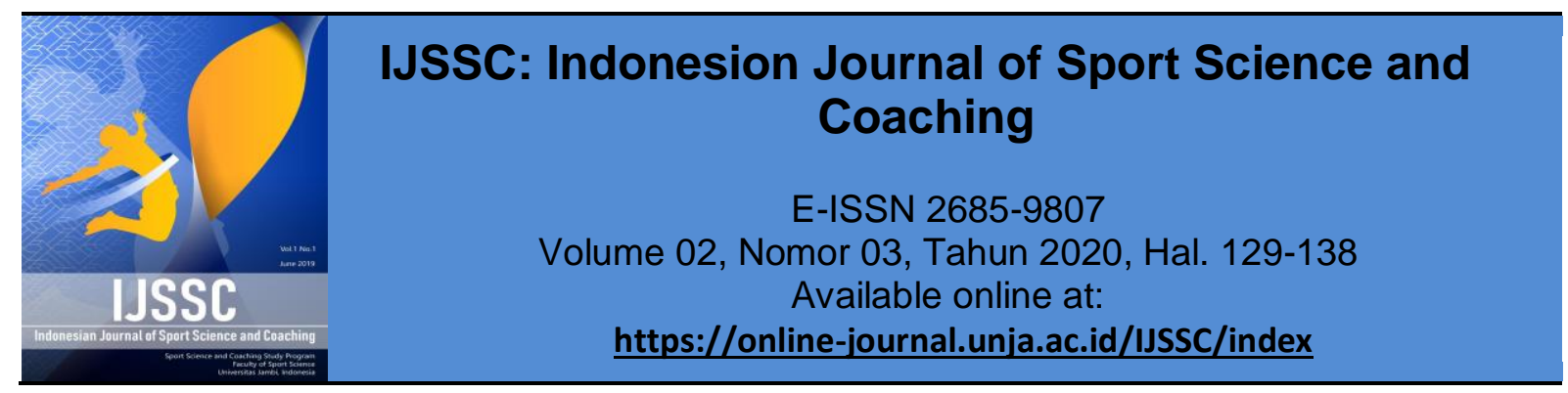

Research Article

OPEN ACCESS

\title{
Pengembangan Model Pembelajaran Renang Melalui Materi Pengenalan Aktivitas Air Di Sekolah Dasar
}

\section{(The Development of a Swimming Learning Model Through The Introduction of Water Activities in Primary School)}

\author{
Herdianto*, lyakrus, Meirizal Usra
}

Fakultas Keguruan dan IImu Pendidikan, Universitas Sriwijaya

JI. Raya Palembang-Prabumulih, Indralaya, Ogan Ilir, Sumatera Selatan 30662, Indonesia

${ }^{*}$ Corresponding author. herdiabifaisal@gmail.com

\begin{tabular}{|c|c|}
\hline Informasi Artikel & ABSTRACT \\
\hline \multirow[t]{2}{*}{$\begin{array}{l}\text { Submit: } 21-09-2020 \\
\text { Diterima: } 30-10-2020 \\
\text { Dipublikasikan: } 08-11-2020\end{array}$} & $\begin{array}{l}\text { This study aims to develop a swimming learning model through the introduction } \\
\text { of water activities in elementary schools. The learning model is in accordance } \\
\text { with the psychomotor characteristics of students and helps students in learning } \\
\text { the introduction of water activities. The method used in this research is the } \\
\text { method of development. The subjects in this study were } 56 \text { students of grade II } \\
\text { SD Banding Agung. This development research uses the ADDIE development } \\
\text { model consisting of the stages of Analysis, Design, Development, } \\
\text { Implementation and Evaluation. Data collection techniques in this study include } \\
\text { validation sheets, questionnaires, and tests of basic water activity abilities. } \\
\text { Expert testing is carried out by material experts and psychomotor experts. The } \\
\text { results of the validation of the resulting learning model meet the validation } \\
\text { requirements according to the student's psychomotor stages and learning } \\
\text { objectives. The one to one test stage obtained the results of the questionnaire } \\
\text { all the sample students agreed that mode. In the small group test, the average } \\
\text { gainscore result was } 0.75 \text { and was included in the high category and the results } \\
\text { of the student motivation questionnaire were 92.5\%. At the implementation } \\
\text { stage of the learning model, the learning results obtained from a gainscore of } \\
0.78 \text { are in the high category and } 82.975 \% \text { agree that the model used is fun } \\
\text { and provides motivation to dare to play in the water. The implication of this } \\
\text { research is that the development of a swimming learning model through the } \\
\text { introduction of water activities is valid, effective and practical and can be used } \\
\text { by physical education teachers in elementary schools. }\end{array}$ \\
\hline & Key words: Learning Model, capacity building, water activities. \\
\hline Penerbit & ABSTRAK \\
\hline $\begin{array}{l}\text { Jurusan Pendidikan Olah Raga dan } \\
\text { Kepelatihan FKIP Universitas Srwijaya } \\
\text { Jambi- Indonesia }\end{array}$ & $\begin{array}{l}\text { Penelitian ini bertujuan untuk mengembangkan model pembelajaran renang } \\
\text { melalui materi pengenalan aktivitas air di sekolah dasar. Model pembelajaran } \\
\text { tersebut sesuai dengan karakteristik psikomotorik siswa serta membantu siswa } \\
\text { dalam pembelajaran pengenalan aktivitas air. Metode yang digunakan dalam } \\
\text { penelitian ini adalah metode pengembangan. Subjek dalam penelitian ini } \\
\text { adalah siswa kelas II SD banding Agung sebanyak } 56 \text { orang siswa. Penelitian } \\
\text { pengembangan ini menggunakan model pengembangan ADDIE terdiri atas } \\
\text { tahapan Analysis, Design, Development, Implementation dan Evaluation Teknik } \\
\text { pengumpulan data dalam penelitian ini yaitu meliputi lembar validasi, angket, }\end{array}$ \\
\hline
\end{tabular}


dan tes kemampuan dasar aktivitas air. Uji ahli dilakukan oleh ahli materi dan ahli psikomotorik. Hasil validasi model pembelajaran yang dihasilkan memenuhi syarat validasi sesuai dengan tahapan psikomotorik siswa dan tujuan pembelajaran. Tahap uji one to one didapatkan hasil angket semua siswa sample setuju bahwa mode. Pada tes small group didapatkan rata-rata hasil gainscore 0,75 dan masuk dalam kategori tinggi dan hasil angket motivasi siswa didapatkan 92,5\%. Pada tahap implementasi model pembelajaran didapatkan hasil gainscore 0,78 termasuk kategori tinggi dan $82,975 \%$ setuju kalau model yang digunakan menyenangkan dan memberikan motivasi untuk berani bermain di air. Implikasi dari penelitian ini bahwa pengembangan model pembelajaran renang melalui materi pengenalan aktivitas air ini valid, efektif dan praktis serta dapat digunakan bagi guru penjas di sekolah dasar

Kata kunci: Model Pembelajaran, peningkatan kemampuan, aktivitas air.

This IJSSC : Indonesian Journal of Sport Science and Coaching is licensed under a CC BY-NCSA (Creative Commons Attribution-ShareAlike 4.0 International License)

\section{PENDAHULUAN}

Membiasakan anak dengan aktifitas air sejak awal usia pertumbuhan sangat baik untuk meransang pertumbuhan dan perkembangan anak seperti menguatkan otot-otot tangan dan kaki serta melatih keberanian anak. Sejalan dengan itu (Sumarni, 2012) mengatakan pada usia dini yang merupakan usia keemasan (golden age) dalam kehidupan manusia, seorang anak mengalami perkembangan yang sangat pesat dalam berbagai aspek kepribadianya, secara fisik dan mental. Pendapat ini juga sesuai dengan Usra (Usra, 2014) pada tingkat sekolah dasar siswa membutuhkan kebugaran jasmani yang sangat baik agar dapat menyelesaikan seluruh tugas-tugas yang dikerjakan tanpa merasa kelelahan dan dapat melanjutkan pekerjaan yang lain dengan mengambil keputusan yang tepat.

Pengenalan air perlu diberikan dalam pembelajaran di sekolah sejak dini agar anak mengenal cara aman beraktivitas di air. Untuk memulai memperkenalkan olahraga renang pada anak menurut (Widiastuti \& Hamamah, 2017) menjelaskan bahwa olahraga renang termasuk salah satu keterampilan yang harus dipelajari terutama bagi anak-anak. Hal ini senada dengan lyakrus (lyakrus, 2018) mengatakan bahwa keberhasilan pendidikan jasmani di sekolah dalam membentuk komponen fisik akan menunjang keberhasilan proses pembelajaran lainnya. Selain itu menurut (Hernawan et al., 2020) manfaat lain yang dapat diambil dari renang ialah sebagai sarana bersosialisasi dan berinteraksi dengan orang lain, menambah kepercayaan pada diri sendiri, dan dapat digunakan sebagai kegiatan rekreatif karena rangsangan dingin dapat menyegarkan tubuh dan perasaan. Pemilihan pengenalan aktifitas air sebagai isu penelitian ini didasari oleh pentingnya pembelajaran pengenalan aktifitas air sebagai dasar pembelajaran renang serta ditemukannya permasalahan dalam proses pembelajarannya di sekolah dasar.

Olahraga renang menurut (Mulyana, 2015) termasuk salah satu keterampilan yang harus dipelajari terutama bagi anak-anak. Olahraga renang adalah olahraga 
yang menuntut keberanian, karena anak yang belajar renang harus berani memasukkan kepala kedalam air, membuang nafas di dalam air, meluncur, mengapung, dan melakukan sesuatu gerakan didalam air. Sehingga pembelajaran pengenalan air dibutuhkan oleh siswa yang belum pernah sama sekali belajar berenang, karena kemungkinan siswa ada yang masih takut masuk ke dalam kolam renang. Untuk itu, guru hendaknya memahami benar bentuk-bentuk pengenalan air.

Pada pembelajaran pengenalan aktifitas air ini diharapkan kemampuan siswa pada aspek psikomotorik dapat tercapai yaitu kemampuan, dan keterampilan mengambang atau mengapung dan meluncur pada permukaan air. Namun demikian kenyataan yang ada dilapangan terdapat permasalahan yang terjadi pada proses pembelajaran pengenalan aktifitas air untuk anak sekolah dasar yaitu, anak cenderung takut untuk masuk ke dalam air, anak takut membuat gelembung dengan membuang nafas di dalam air, dan anak belum memiliki keberanian untuk melakukan gerakan meluncur dengan sendiri. Agar masalah dalam pembelajaran renang tersebut dapat teratasi hendaknya siswa telah mengenalkan renang terutama melalui pengenalan aktifitas air kepada anak diawal masa pertumbuhan dan perkembangannya karena akan lebih efisien.

Peneliti melakukan observasi tentang analisis kebutuhan kepada guru yang mengajar penjas terutama pada materi renang, melalui observasi dengan menggunakan daftar ceklist observasi pada siswa 17 anak. Hasil observasi tersebut menunjukan bahwasanya sebanyak 6 anak atau sebanyak 35\% anak tidak takut dengan air, ini ditandai dengan anak langsung mau diajak masuk kedalam air dan merasa senang. Selanjutnya 11 anak atau sebanyak $55 \%$ anak takut dengan air, ini ditandai dengan anak menangis dan merasa tidak nyaman serta masih harus menggunakan pelampung. Akan tetapi dari 11 anak yang masih merasa takut dengan air peneliti dapat mengelompokkan lagi menjadi beberapa katagori yaitu sangat takut dan cukup berani, apabila anak yang takut mereka benar-benar takut dan menangis serta tidak mau melaksanakan instruksi yang diberikan. Apabila anak yang cukup berani mereka mau diajak masuk kedalam air akan tetapi tidak mau memasukan kepala mereka.

Berdasar analisis kebutuhan diatas membuat peneliti berupaya untuk mencari solusi yang efektif dan efisien untuk mencari solusi dari permasalahan yang tersebut. Peneliti melakukan studi literatur untuk mencari karakteristik anak usia dini agar didapat metode yang baik sebagai solusi dari permasalahan yang dihadapi. Peneliti juga mendapatkan beberapa teori terkait dengan anak usia sekolah dasar yang disesuaikan dengan karakter subjek yang akan diteliti. Usia sekolah dasar adalah masa bermain dimana hal ini identik dengan mereka. Oleh karena itu peneliti menggunakan bermain model dalam pembelajaran renang pada meteri pengenalan aktifitas air yang akan dilakukan. Dengan harapan pengembangan model pembelajaran renang ini dapat membantu anak-anak sekolah dasar khususnya pada kelas 1,2 dan 3 dalam penguasaan pengenalan air, (Susanto, 2013) usia sekolah dasar merupakan usia sangat penting bagi tumbuh kembang dan termasuk masa yang tepat untuk memperkenalkan keterampilan dasar berenang. Pengembangan 
model pembelajaran ini diperlukan sejalan dengan pendapat (Arifin, 2013) model pengembangan gerak dasar renang di sekolah dasar harus disesuaikan dengan tahap pertumbuhan dan perkemba- ngan anak agar hasil yang dicapai sesuai dengan tujuan pembelajaran yang diinginkan.

Berdasarkan hasil studi pendahuluan yang dilakukan oleh peneliti bahwa permasalahan-permasalahan dalam proses pembelajaran renang ini juga terjadi di sekolah tempat peneliti melakukan observasi yaitu SD Negeri1 Banding Agung. Menurut penulis ini merupakan tantangan bagi para guru penjaskes agar dalam melaksanakan proses pembelajaran selalu mengembangkan sikap kreatif dan inovatif agar proses pembelajaran dapat berjalan dengan lancar dan siswa merasa puas serta menyenangkan. Hal ini disebabkan oleh beberapa faktor yaitu model pembelajaran yang diterapkan guru pendidikan jasmani di sekolah hanya berupa kegiatan bermain di dalam air dengan masing-masing anak menggunakan pengaman atau pelampung tanpa adanya langkah-langkah yang sistematis dan terstruktur sehingga dalam proses pembelajaran melibatkan banyak guru selain itu model pembelajaran renang yang di gunakan belum sesuai dengan tuntutan kurikulum, cara penyampaian materi ajar kurang efektif, tidak ada target atau capaian yang yg jelas dalam pembelajaran serta tingginya tingkat resiko di air kerena menerapan model yang kurang tepat yang mengakibatkan siswa lambat dalam menguasai gerakan-gerakan renang karena anak cenderung takut untuk masuk ke dalam air, takut membuat gelembung udara di dalam air dan anak takut untuk melakukan gerakan meluncur dengan sendiri.

Sebaiknya untuk meningkatkan kemampuan serta semangat belajar siswa dalam mengikuti pelajaran renang maka dirasakan perlu untuk mengembangkan model pembelajaran renang melalui pengenalan aktivitas air, hal ini dikarenakan adanya fasilitas kolam kolam renang umum serta lokasi lingkungan sekolah yang berada di seputaran dananu ranau yang cukup memadai untuk menerapkan pembelajaran renang melalui materi pengenalan aktifitas air. Berdasarkan pengamatan dan observasi diatas maka peneliti tertarik untuk melakukan penelitian dengan judul "Pengembangan Model Pengenalan Aktivitas Air di Sekolah Dasar "

Adapun tujuan dari penelitian ini adalah sebagai berikut. Pertama untuk menghasilkan model pembelajaran renang melalui materi pengenalan aktivitas air yang instruksional dan dapat di diterapkan dalam pembelajaran renang di sekolah. Kedua mengetahui efektivitas Pengembangan Model Pembelajaran Renang Melalui Materi Pengenalan Aktivitas Air yang telah dikembangkan terhadap hasil belajar siswa di Sekolah Dasar.

\section{METODE PENELITIAN}

Model desain instruksional yang dipilih peneliti untuk mengembangkan model pembelajaran yang akan digunakan adalah model ADDIE. Model ini dipilih karena Model ADDIE memiliki pendekatan teknologi pendidikan dimana model ini lebih cocok untuk mengembangkan model pembelajaran dibandingkan desain instruksional lainnya seperti pendapat Pargito dalam (Septiani, 2016). Sesuai 
dengan namanya, model ADDIE terdiri lima tahap, yaitu: (A) Analysis, (D) Desain, (D) Development, (I) Implementaion dan (E) Evaluation. Langkah- langkah pengembangannya dapat dilihat pada Gambar 1 berikut.

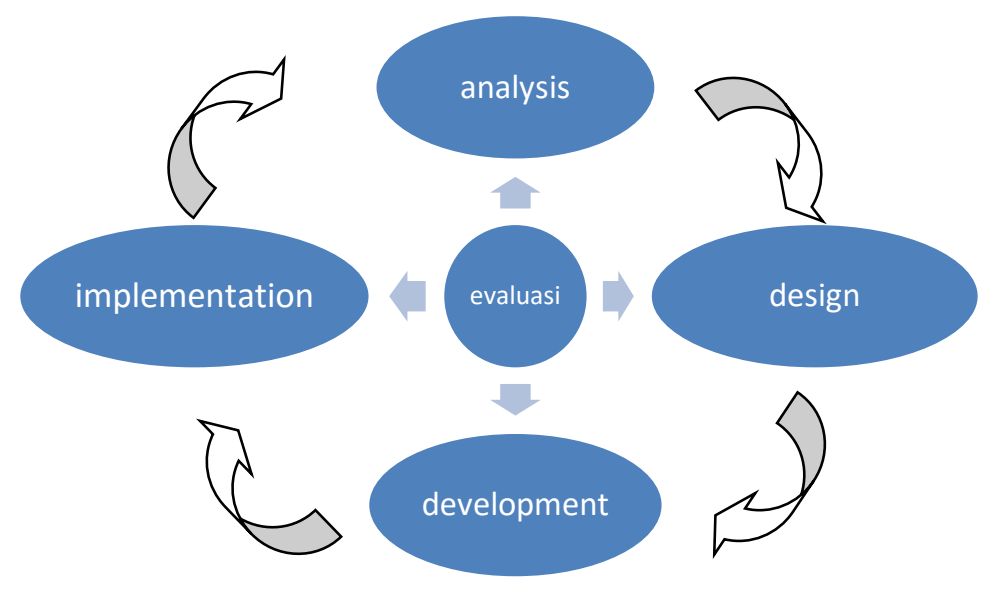

Gambar 1. Diagram Desain Pengembangan Model Pembelajaran Addie

Uji coba model atau produk juga untuk melihat sejauh mana produk yang dibuat dapat mencapai sasaran dan tujuan. Subjek dalam penelitian ini adalah seluruh siswa kelas 2 di Sekolah Dasar Negeri 1 Banding Agung tahun pelajaran 2018/2019 yaitu sebanyak 56 siswa. Penelitian diadakan pada Sekolah Dasar Negeri 1 Banding Agung. Sekolah tersebut terletak di Kecamatan Banding Agung Kabupaten Ogan Komering Ulu Selatan. Waktu pelaksanaan penelitian adalah selama 4 ( empat) bulan yaitu dimulai pada bulan April 2020 sampai dengan bulan Juli 2020.

Pengumpulan data dalam kegiatan pengembangan model pembelajaran renang melalui materi pengenalan aktivitas air menggunakan: (a) Catatan lapangan (field note), (b) Angket, dan (c) Tes Unjuk Kerja, Dilakukan oleh anak untuk memperoleh hasil pada uji efektifitas pengenalan air, dengan penilaian unjuk kerja menggunakan skala Guttman. Adapun untuk menilai hasil kerja dengan "skor 1-4" sesuai level yang dicapai anak.

$$
\text { Nilai hasil akhir }=\frac{\text { skor yang didapat }}{\text { skor maksimal }}
$$

Tahapan yang ditempuh untuk menganalisis data terhadap hasil tes belajar, yakni pretest dan posttest, masing-masing ialah pertama memberikan skor dalam rentang 0-100 terhadap kinerja aktivitas pengenalan air. Kedua, memasukkan skor masing-masing siswa ke dalam tabel hitung atau mentabulasi skor siswa. Ketiga, menghitung gainscore masing-masing siswa dengan rumus sebagai berikut:

$$
\mathrm{g}=\frac{\mathrm{S}_{\text {post }}-S_{\text {pre }}}{S_{\max }-S_{\text {pre }}}(\text { Meltzer, 2002) }
$$


Tabel 1. Klasifikasi Interpretasi N-Gain

\begin{tabular}{ll}
\hline Besar presentase & Interpretasi \\
\hline $\mathrm{g} \geq 0,7$ & Tinggi \\
$0,3<\mathrm{g}<0,7$ & Sedang \\
$\mathrm{g} \leq 0,3$ & Rendah \\
\hline
\end{tabular}

\section{HASIL PENELITIAN DAN PEMBAHASAN}

Pada tahap analisa kebutuhan, peneliti melakukan analisis yang ada pada silabus yaitu kompetensi dasar Pendidikan Jasmani jenjang Sekolah Dasar kelas 1. Selanjutnya setelah melakukan analisis kompetensi dasar peneliti melakukan observasi tentang analisis kebutuhan kepada guru yang mengajar penjas terutama pada materi renang. melalui observasi dengan jumlah siswa 17 anak. Hasil observasi tersebut menunjukan bahwasanya sebanyak 6 anak atau sebanyak 35\% anak tidak takut dengan air, ini ditandai dengan anak langsung mau diajak masuk kedalam air dan merasa senang. Selanjutnya 11 anak atau sebanyak $55 \%$ anak takut dengan air, ini ditandai dengan anak menangis dan merasa tidak nyaman serta masih harus menggunakan pelampung. Hasil observasi ini sejalan dengan pendapat (Usra, 2014) rasa takut dan tidak ada jaminan keselamatan merupakan factor utama yang menyebabkan sulit melakukan gerakan.

Pengembangan model pembelajaran pengenalan air ini beranjak dari keberhasilan peneliti pendahulu dalam mengembangan model pembelajaran pengenalan air seperti penelitian yang dilakukan oleh Nur Sita Utami dengan judul Model Pengenalan Air Bagi Siswa Taman Kanak-Kanak. Pada penelitian pengembangan yang dilakukan (Utami et al., 2014) didapatkan model pengenalan air bagi siswa TK sesuai dengan kurikulum dan karakteristik siswa TK kelompok B. Model pengenalan air bagi siswa TK kelompok B efektif dilaksanakan dalam proses pembelajaran karena dapat mentransfer nilai-nilai pada aspek kognitif, afektif, dan psikomotor. Maka dari itu peneliti kemudian mengembangkan model pembelajaran yang cocok untuk dikembangkan pada pembelajaran renang di sekolah dasar.

Tahap desain dilakukan dengan mengembangkan produk awal yang berupa model pembelajaran. Dalam proses ini akan dilakukan analisa desain produk yaitu draft yang nantinya akan divalidasi oleh para ahli sebelum di ujicobakan kepada subjek penelitian. Pengembangan model pembelajaran pengenalan air pada anak usia dini ini diharapkan menjadi produk yang dapat dikembangkan secara sistematis dan logis, sehingga produk dapat membantu siswa mencapai tujuan pembelajaran yang akan dicapai. Adapun model pembelajaran pengenalan air pada anak usia dini adalah sebagai berikut: 1. Pengenalan air diatas kolam. 2. Pengenalan air didalam kolam. 3. Membuang nafas didalam air. 4. Mengapung. 5. Mendorong diri dan meluncur lima aspek tersebut dikembangkan menjadi item model

Dalam tahap pengembangan ini mulai dikembangkan produk dan juga mengembangkan instrumen validasi yang bertujuan untuk mengukur atau menilai produk yang sedang dikembangkan. Setelah produk yang berupa model pembelajaran dibuat maka akan dilakukan self evaluation yaitu proses konsultasi 
mengenai model pembelajaran yang sedang dikembangkan dengan dosen pembimbing serta berdiskusi dengan teman sejawat yang hasilnya bisa disebut sebagai prototype 1 . Hasil dari prototype 1 tadi akan diberikan kepada validator untuk dilakukan expert review dan uji small group.

Produk akhir dari penelitian ini adalah model pembelajaran ini divalidasi oleh dua orang ahli di bidangnya yakni ahli materi dan ahli psikomotorik. Peneliti meminta Bpk Dr. Alfroki artha, M.Pd sebagai ahli materi dan bapak Muhammad Arief, M.Pd ahli psikomotorik. Dari hasil evaluasi lembar validasi yang diberikan kepada para ahli diketahui bahwa model pembelajaran yang dikembangkan sudah valid

Setelah model pembelajaran yang dikembangkan sudah dalam bentuk spesifik prototype divalidasi oleh para pakar, model pembelajaran kemudian diujikan dalam tahap uji one-to-one untuk mengetahui keefektifan model pembelajaran. Uji one-toone ini diujikan pada 3 orang siswa yang akan melakukan penilaian terhadap model pembelajaran yang sebelumnya telah divalidasi oleh para ahli. Semua siswa setuju bahwa kegiatan belajar mengajar menggunakan model pembelajaran ini menarik, lebih berani dan membantu siswa dalam kegiatan pengenalan aktivitas air.

Pada tahap small group peneliti menguji cobakan model pembelajaran kepada 10 orang siswa kelas 1 berjenis kelamin 5 orang perempuan dan 5 orang laki-laki. didapatkan bahwa ada tujuh siswa yang mendapatkan nilai interpretasi gain tinggi, dua orang mendapat nilai interpretasi gain sedang, dan satu siswa mendapat nilai interpretasi gain rendah. Maka dapat disimpulkan bahwa model pembelajaran pengenalan aktivitas air sangat berpengaruh untuk hasil belajar siswa dalam tahap small group. Dari hasil angket yang didapatkan pada uji kelompok kecil ini didapatkan rata-rata $92,5 \%$ setuju kalau model yang digunakan menyenangkan dan memberikan motivasi untuk berani bermain di air.

Pada tahapan implementasi, model pembelajaran yang dikembangkan diimplementasikan pada siswa di SD 1 Banding Agung. Implementasi model pembelajaran ini dilakukan kepada siswa kelas 2 SDN 1 Banding Agung, yang terdiri dari 56 siswa dengan 30 siswa perempuan dan 26 siswa laki- laki. Peneliti akan memberikan soal pretest dan posttest. Pemberian pretest bertujuan untuk mengetahui batas kemampuan dimiliki siswa. Diperoleh nilai gain diatas sebesar 0,78 telah terlihat bahwa penggunaan model pembelajaran yang telah dikembangkan sangat berpengaruh positif terhadap hasil belajar siswa. Hal itu telah terlihat dalam uji lapangan yang telah dilakukan peneliti dikelas 2 SDN 1 Banding Agung. Dari hasil angket yang didapatkan pada uji kelompok besar ini didapatkan rata-rata 82,975\% setuju kalau model yang digunakan menyenangkan dan memberikan motivasi untuk berani bermain di air.

Tujuan pembelajaran pengenalan air adalah untuk membentuk sikap, kemampuan, dan keterampilan mengambang atau mengapung dan meluncur pada permukaan air. Melalui kemampuan mengapung dan meluncur akan mempermudah siswa melakukan bentuk gerakan yang akan dipelajari. Berdasarkan perolehan angka pada presentase di atas dapat disimpulkan bahwa model pengenalan air yang dikembangkan dapat dan layak untuk digunakan dalam pengenalan air pada anak 
usia dini serta efektif untuk meningkatkan kemampuan dasar renang yaitu pernafasan, meluncur dan mengapung.

Banyak cara yang dilakukan oleh guru dalam kegiatan pengenalan aktivitas air pada anak didiknya. (Rusilowati et al., 2012) mengatakan paradigma pendekatan pembelajaran saat ini telah berubah dari yang semula berpusat pada guru menjadi pembelajaran berpusat pada siswa hal ini tentunya harus disikapi oleh guru agar siswa memahami berbagai model pembelajaran yang akan di terapkan. Pengembangan model pembelajaran melalui materi pengenalan aktivitas air disekolah dasar ini mengacu pada karakteristik siswa Sekolah Dasar berkaitan dengan aktivitas fisik yaitu umumnya anak senang bermain, senang bergerak, senang bekerja dalam kelompok dan senang praktik langsung (Burhaein, 2017), sehingga ketika model pembelajaran ini diimplementasikan siswa dengan mudah bisa mengikuti setiap kegiatan yang dilakukan sehingga model pembelajaran ini dinyatakan praktis. Menurut (Plomp \& Nieveen, 2013) practicality' refers to the extent that users (and other experts) consider the intervention as clear, usable and costeffective in 'normal' conditions. '.

Selain dari peningkatan kemampuan aktivitas dasar pengenalan air pengembangan model pembelajaran ini juga meningkatkan motivasi belajar anak, sebelum menggunakan model pembelajaran ini anak cenderung takut untuk masuk kekolam renang tetapi setelah menggunakan model pembelajaran renang melalui materi pengenalan air di sekolah dasar ini 92,5\% anak menyatakan bahwa pembelajaran yang dilakukan menyenangkan. Pembelajaran yang menyenangkan ini akan membuat anak terus termotivasi untuk belajar berenang dan salah satunya permasalahan yang dihadapi ketika belajar berenang dikolam yaitu rasa takut anak terhadap air bisa dikurangi bahkan dihilangkan. Kegiatan pembelajaran yang menyenangkan ini membuktikan beberapa pendapat sebelumnya salah satunya dalam (Puspitorinil et al., 2017) menerangkan bahwa anak akan semakin cepat untuk menguasai keterampilan berenang apabila suasana dalam pembelajaran tersebut menyenangkan, aman dan nyaman serta menggunakan metode bermain dalam pelaksanaannya. Dikarena pembelajaran renang yang wajib diberikan mulai dari SD sampai SMA maka bisa disimpulkan jika anak sudah memiliki kemampuan dasar aktivitas air mereka tidak akan kesulitan untuk mencapai tujuan pembelajaran untuk tingkatan selanjutnya.

Evaluasi adalah tahap terakhir dari model pengembangn EDDIE. Karena dalam penelitian ini hanya sampai uji coba terbatas, maka evaluasi yang dimaksud disini adalah evaluasi dari kegiatan implementsi. Hasil evaluasi didapat dari saran guru dan siswa selama uji coba tersebut dilaksanakan. berdasarkan hasil evalusi didapatkan jika model pembelajaran pengenalan air sudah efektif dalam meningkatkan kemampuan siswa, menyenangkan dan memberikan motivasi untuk berani bermain di air.

\section{KESIMPULAN}

Berdasarkan hasil pembahasan dalam penelitian pengembangan model pembelajaran renang melalui materi pengenalan aktivitas air di sekolah dasar dapat 
disimpulkan bahwa, model pembelajaran renang yang telah dikembangkan sudah valid. Kevalidan model tersebut diperoleh dari perolehan nilai gain sebesar 0,78 hal ini mengindikasikan bahwa penggunaan model pembelajaran yang telah dikembangkan sangat berpengaruh positif terhadap hasil belajar siswa.serta model pembelajaran yang telah dikembangkan telah teruji kualitasnya dan dapat membantu siswa mencapai tujuan pembelajaran. ini layak digunakan dalam proses pembelajaran. Model pembelajaran renang yang telah dikembangkan sudah praktis. Hal ini dapat dilihat dari hasil angket yang didapatkan pada uji kelompok kecil ini didapatkan rata-rata $92,5 \%$ setuju kalau model yang digunakan menyenangkan dan memberikan motivasi untuk berani bermain di air. Adapun hasil penilaian siswa mengenai model pembelajaran renang yang dikembangkan dengan kategori sangat praktis, sehingga model pembelajaran yang dikembangkan sangat praktis untuk digunakan siswa dalam proses pembelajaran. Model pembelajaran renang yang dikembangkan memiliki efektivitas terhadap hasil belajar siswa. Hal ini dapat dilihat dari hasil posttest siswa pada tahap uji coba produk di lapangan. Hasil belajar siswa pada saat pretest dengan kategori sangat kurang sedangkan hasil belajar siswa pada saat posttest dengan kategori nilai $\mathrm{N}$-gain score termasuk kategori tinggi.

\section{UCAPAN TERIMA KASIH}

Ucapan terima kasih kepada Dr. lyakrus, M.Kes. selaku ketua Program Studi Magister Pendidikan Olahraga dan Pembimbing I Serta Dr. Meirizal Usra, M.Kes. selaku Pembimbing II yang telah sabar dan ikhlas memberikan bimbingan, petunjuk, nasehat, dan motivasi kepada penulis untuk menyelesaikan tesis ini.

\section{DAFTAR PUSTAKA}

Arifin, B. (2013). Pengembangan gerak dasar renang untuk anak sekolah dasar. Pemikiran Dan Pengembangan SD, 1(1), 1-8.

Burhaein, E. (2017). Aktivitas Fisik Olaharaga untuk Pertumbuhan dan Perkembangan Siswa SD. Indonesian Journal of Primary Education, 1, 51-58.

Hernawan, Widiastuti, Timur, A. I., \& Pradityana, K. (2020). Mengenalkan anak dengan dunia air sejak dini. March. https://doi.org/10.21009/JPUD.122.06

lyakrus. (2018). Pendidikan Jasmani , Olahraga, dan Prestasi. Jurnal Ilmu Olahraga Dan Kesehatan, 7. https://doi.org/10.36706/altius.v7i2.8110

Meltzer, D. E. (2002). The relationship between mathematics preparation and conceptual learning gains in physics: A possible "hidden variable"' in diagnostic pretest scores. In Am. J. Phys.

Mulyana, D. (2015). Pelatihan Cabang Olahraga Renang (Disajikan). UPI.

Plomp, T. (SLO), \& Nieveen, N. (SLO). (2013). Educational Design Research Educational Design Research. Educational Design Research, 1-206.

Puspitorinil, W., Kurniatil, R., \& Tangkudung, J. (2017). Model Pembelajaran Berorientasi Fundamental dengan Permainan Air Untuk Anak 5 - 6 Tahun. Pendidikan Usia Dini, II, 333-341. https://doi.org/10.21009/JPUD.112.11

Rusilowati, A., Hartono, \& Supriyadi. (2012). Pengembangan Model Pembelajaran Better Teaching and Learning Berkarakter untuk Membekali Kompetensi Pedagogi Mahasiswa Calon Guru. 29, 83-92. 
https://doi.org/10.15294/jpp.v29i2.5649

Septiani, L. (2016). Pengembangan Software Berhitung dalam Pembelajaran Matematika. JKPM, 01(02), 267-278.

Sumarni, S. (2012). Peningkatan Kecerdasan Jamak Anak Usia Dini Melalui Bermain. Forum Kependidikan, 28, 143-154.

Susanto, E. (2013). Pengembangan Tes Keterampilan Renang Anak Usia Prasekolah. Jurnal Penelitian Dan Evaluasi Pendidikan, 14(2), 146-165. https://doi.org/10.21831/pep.v14i2.1076

Usra, M. (2014). Aplikasi Aktivitas Fisik Siswa Sekolah Dasar Sebagai Upaya Peningkatan Kebugaran Jasmani. Inovasi Sekolah Dasar, I, 157-165.

Utami, N. S., Yogyakarta, U. N., \& Yogyakarta, U. N. (2014). Jurnal Keolahragaan, Volume 2 - Nomor 2, 2014. 2(3), 204-215.

Widiastuti, \& Hamamah, F. (2017). Model Pembelajaran Renang (Fh) Bagi Siswa Prasekolah. JPUD - Jurnal Pendidikan Usia Dini, 11(2), 358-368.

https://doi.org/10.21009/jpud.112.13 